\title{
PERENDAMAN PLAT RESIN AKRILIK POLIMERISASI PANAS PADA EKSTRAK BUNGA ROSELLA (Hibiscus sabdariffa L.) TERHADAP PERUBAHAN WARNA
}

\author{
Kadek Ayu Wirayuni \\ Bagian Prostodonsia, Fakultas Kedokteran Gigi, Univwesitas Mahasaraswati, Denpasar \\ email: wirayunikdkgmail.com
}

\begin{abstract}
The color of acrylic resin plate is one of particular concern, because it's related with aesthetics of oral tissue. An acrylic resin can absorb colored fluids and cause a color change, which reduces the aesthetic value of the denture. This study aims to determine discoloration of acrylic resin plate heat cured after submersion of rosella flower extract. This study used 25 samples, divided into 5 samples for $20 \%$ rosella flower extract, 5 samples for $40 \%$ rosella flower extract, 5 samples for $60 \%$ rosella flower extract, 5 samples negative control (aquades) and 5 samples positive control (fifftydent). Soaking time is 10 minutes per day for a week. The type of research used was experimental pretest-posttest with control group design. Measurements using Adobe Photoshop and the CIELab color measurement system. Furthermore, statistically using the Shapiro wilk test, Leven's test, One Way Anova and Least Significant Diffence. The results of the study are shows the mean color change of CIELab $(\Delta \mathrm{E})$ in the five groups after treatment significantly different ( $\mathrm{p}<0.05)$. Least Significant Difference - test (LSD) test shows the results of immersion test on extract $20 \%$ and $40 \%$ are not different from negative controls, extract $60 \%$ is different from negative controls, extract $60 \%$ is same like positive control. The conclusions in this study are concentration of immersion with rosella flower (Hibiscus sabdariffa L.) extract $20 \%$ and $40 \%$ can't change the color of the acrylic resin plate heat cured, however extract rosella flowers (Hibiscus sabdariffa L.) 60\% can change the color of acrylic resin plate heat cured.
\end{abstract}

Keywords: Acrylic resin heat cured, rosella flower extract, color, denture cleanser.

\section{PENDAHULUAN}

Kesehatan gigi dan mulut merupakan salah satu faktor terpenting dalam peningkatan kesehatan tubuh secara menyeluruh. Rongga mulut merupakan pintu utama masuknya nutrisi kedalam tubuh, gigi memiliki peranan yang sangat penting untuk memiliki kualitas hidup yang baik. Gigi dan mulut yang sehat dapat dilihat dari jumlah gigi yang dapat dipertahankan selama masa kehidupan. Kehilangan gigi sebagian maupun seluruh gigi dapat menyebabkan gangguan mastikasi, bicara, dan estetika.

Penggunaan gigi tiruan adalah salah satu cara merehabilitasi gigi yang hilang. Kehilangan gigi secara tidak langsung dapat mengurangi kualitas hidup seseorang, ditinjau dari segi fungsi, psikologis, dan hubungan interpersonal seseorang. ${ }^{1}$ Perawatan dengan gigi tiruan sangat diperlukan untuk mencegah perubahan degeneratif yang timbul sebagai akibat hilangnya gigi dan juga untuk mengembalikan fungsi pengunyahan, estetik, dan fonetik. ${ }^{2}$

Gigi tiruan lepasan adalah gigi tiruan yang menggantikan sebagian atau semua gigi, dapat dilepas dan dipasang kembali di dalam mulut. Salah satu komponen gigi tiruan lepasan yaitu basis gigi tiruan dapat didefenisikan sebagai bagian dari gigi tiruan yang bersandar pada jaringan pendukung dan tempat anasir gigi tiruan dilekatkan. Bahan dasar basis gigi tiruan yang paling sering digunakan yaitu jenis polimerisasi panas (heat cured). Resin akrilik dipakai sebagai basis gigi tiruan oleh karena bahan ini memiliki keuntungan tidak toksik, tidak mengiritasi dan tidak larut dalam cairan mulut. Namun resin akrilik juga memiliki kekurangan yaitu mudah patah bila jatuh pada permukaaan yang keras, serta mengalami perubahan warna setelah beberapa waktu dipakai dalam mulut. ${ }^{3}$

Stabilitas warna merupakan karakteristik klinis yang sangat penting pada bahan restorasi gigi dan bahan basis gigi tiruan, dapat berpengaruh terhadap perubahan warna suatu bahan. Perubahan warna ini dapat disebabkan oleh dua faktor yaitu intrinsik dan ekstrinsik. Faktor intrinsik meliputi faktor bahan resin akrilik itu sendiri, baik oleh karena sifat material, struktur kimia, maupun monomer yang digunakan, sedangkan faktor ekstrinsik adalah stain akibat absorpsi bahan pewarna dari sumber-sumber eksogen seperti teh, kopi, minuman ringan, zat pewarna alami dan bahan pembersih gigi tiruan. ${ }^{4}$

Zat warna alam (pigmen) adalah zat warna yang secara alami terdapat dalam tanaman maupun hewan. Zat warna alam dapat dikelompokkan sebagai warna hijau, kuning, dan merah. Bunga rosella merupakan salah satu contoh pewarna alami. ${ }^{5}$

Bunga rosella (Hibiscus sabdariffa L.) mempunyai potensi sebagai pewarna alami, karena terdapat komponen yang berperan memberikan warna merah pada bunga rosella yaitu pigmen dari golongan antosianin. ${ }^{6}$ Kandungan bunga rosella terdiri dari flavonoid dan antosianin. Antosianin merupakan senyawa metabolit sekunder turunan flavonoid yang banyak tersebar di alam sebagai pigmen alami serta 
bersifat anti bakteri, anti fungi dan antioksidan. Berdasarkan penelitian yang dilakukan menggunakan konsentrasi $40 \%$ menunjukkan bahwa perendaman basis gigi tiruan resin akrilik pada bunga rosella dapat menghambat pertumbuh koloni bakteri dan Candida albicans, karena terdapat kandungan komposisi aktif dari bunga rosella yaitu flavonoid jenis antosianin. ${ }^{7}$

Penelitian yang dilakukan menggunakan bunga rosella dengan konsentrasi $2,5 \%$ memperoleh hasil yaitu terjadi perubahan warna pada basis gigi tiruan berbahan resin akrilik heat cured. ${ }^{8}$ Hasil bertolak belakang pada penelitian menggunakan bunga rosella sebagai pembersih basis akrilik gigi tiruan, hasil penelitian menunjukan bahwa tidak terjadi perubahan warna pada basis gigi tiruan resin akrilik heat cured. ${ }^{9}$

Dari uraian latar belakang diatas, terdapat perbedaan hasil penelitian sebelumnya maka perlu dilakukan penelitian terkait perubahan warna plat resin akrilik polimerisasi panas setelah perendaman ekstrak bunga rosella (Hibiscus sabdariffa L.). Penelitian ini memiliki tujuan antra lain yaitu untuk mengetahui perubahan warna plat resin akrilik polimerisasi panas setelah perendaman ekstrak bunga rosella (Hibiscus sabdariffa L.) dan Untuk mengetahui konsentrasi optimal perendaman dengan ekstrak bunga rosella (Hibiscus sabdariffa L.) terhadap perubahan warna plat resin akrilik polimerisasi panas.

Manfaat yang didapat dari penelitian ini yaitu Menambah wawasan keilmuan di bidang kedokteran gigi khususnya perubahan warna plat resin akrilik polimerisasi panas setelah perendaman ekstrak bunga rosella (Hibiscus sabdariffa L.) terhadap perubahan warna plat resin akrilik polimerisasi panas dan Memberikan informasi bagi pengguna gigi tiruan mengenai perubahan warna basis gigi tiruan yang diakibatkan oleh ekstrak bunga rosella (Hibiscus sabdariffa L.).

\section{BAHAN DAN METODE}

Jenis penelitian yang digunakan dalam penelitian ini adalah penelitian ekperimental dengan menggunakan pretest-posttest dan control group design.

Bahan dan alat yang digunakan dalam penelitian ini antara lain adalah:

1. Bahan :

a. Plat resin akrilik polimerisasi panas sebagai sampel penelitian

b. Ekstrak bunga rosella (Hibiscus sabdariffa L.)

c. Aquades dan fiffydent ${ }^{\circledR}$ denture cleanser sebagai pembanding dengan ekstrak bunga rosella

2. Alat:
a. Camera NIKON DSLR (3100D)
b. Lampu 10 watt
c. Mini studio photo box
d. Laptop (Asus A43E)
e. Stopwatch
f. Timbangan

g. Gelas kimia 1 buah sebagai tempat ukur menakar ekstrak bunga rosella, fifftydent ${ }^{\circledR}$ dan aquades

h. Gelas kimia 5 buah.

i. Neerbeken digunakan sebagai tempat untuk sampel, tempat alat-alat dan bahan agar terjaga kebersihannya

j. Petri disk digunakan sebagai tempat meletakkan dan penyimpanan sampel saat tidak dalam proses perendaman

k. Kertas tissue digunakan untuk digunakan untuk mengeringkan sampel

1. Pinset digunakan untuk mengambil sampel dari dalam ekstrak

m. Handscone digunakan sebagai alat proteksi.

\section{HASIL DAN DISKUSI}

Penelitian eksperimental dengan menggunakan rancangan pretest-posttest with control group design, menggunakan 25 plat resin akrilik polimerisasi panas sebagai sampel, yang terbagi menjadi 5 (lima) kelompok, yaitu kelompok kontrol negatif (aquades), kelompok perlakuan 1 (ekstrak bunga rosella (Hibiscus sabdariffa L.) dengan konsentrasi 20\%), kelompok perlakuan 2 (ekstrak bunga rosella (Hibiscus sabdariffa L.) dengan konsentrasi 40\%), kelompok perlakuan 3 (ekstrak bunga rosella (Hibiscus sabdariffa L.) dengan konsentrasi 60\%) dan kelompok kontrol positif (fifftydent $^{\circledR}$ ). Dalam bab ini akan di uraikan uji normalitas data, uji homogenitas data, dan uji efek perlakuan.

Uji homogenitas data, data perubahan warna CIELab $(\Delta \mathrm{E})$ diuji homogenitasnya dengan menggunakan uji Levene's test, yang bertujuan untuk mengetahui homogen tidaknya data dalam satu penelitian. Hasilnya menunjukkan data homogen ( $>0,05)$, disajikan pada tabel 2 di bawah ini;

Tabel 1. Homogenitas Data Perubahan Warna CIELab $(\Delta \mathrm{E})$ antar kelompok Perlakuan

Homogenitas Data Perubahan Warna CIELab $(\Delta E)$ antar kelompok Perlakuan

\begin{tabular}{lccc}
\hline Variabel & $F$ & $p$ & Keterangan \\
\hline $\begin{array}{l}\text { Perubahan warna } \\
\text { CIELab }\end{array}$ & 0,50 & 0,730 & Homogen \\
$(\Delta \mathrm{E})$ post & & & \\
\hline
\end{tabular}

Uji efek perendaaman bunga rosella (Hibiscus sabdariffa L.).

Analisis efek perlakuan diuji berdasarkan rerata perubahan warna CIELab $(\Delta \mathrm{E})$ antar kelompok setelah perendaman ekstrak bunga rosella. Hasil analisis kemaknaan dengan uji One Way Anova disajikan pada Tabel 3 di bawah ini; 
Tabel 2. Uji Efek Perendaaman Bunga Rosella (Hibiscus Sabdariffa L.).

Perbedaan Rerata Perubahan Warna CIELab $(\Delta \mathrm{E})$ Antar Kelompok Setelah Perendaman Ekstrak Bunga Rosella

\begin{tabular}{cccccc}
\hline Kelompok & $\mathrm{n}$ & rerata & SB & F & P \\
\hline Kontrol Negatif & 5 & 3,34 & 1,87 & & \\
Perlakuan 1 & 5 & 3,07 & 2,38 & & \\
Perlakuan 2 & 5 & 3,45 & 2,19 & 3,11 & 0,038 \\
Perlakuan 3 & 5 & 6,66 & 2,40 & & \\
Kontrol Positif & 5 & 6,85 & 3,04 & & \\
\hline
\end{tabular}

Tabel diatas, menunjukkan bahwa rerata perubahan warna CIELab $(\Delta \mathrm{E})$ kelompok kontrol negatif adalah $3,34 \pm 1,87$, rerata kelompok perlakuan 1 adalah $3,07 \pm 2,38$, rerata keloompok perlakuan 2 adalah $3,45 \pm 2,19$.

Tabel 3. Uji Perbedaan Rerata Antara Dua Kelompok Perlakuan

Analisis Komparasi Perubahan Warna CIELab $(\Delta \mathrm{E})$ Setelah Perlakuan antar Kelompok

\begin{tabular}{|c|c|c|c|c|}
\hline \multicolumn{2}{|c|}{ Kelompok } & \multirow{2}{*}{$\begin{array}{c}\begin{array}{c}\text { Beda } \\
\text { Rerata }\end{array} \\
0,26\end{array}$} & \multirow{2}{*}{$\begin{array}{c}\mathrm{p} \\
0,862\end{array}$} & \multirow{3}{*}{$\begin{array}{c}\text { Ket } \\
\text { Tidak } \\
\text { Berbeda } \\
\text { Tidak } \\
\text { Berbeda }\end{array}$} \\
\hline $\begin{array}{l}\text { Kontrol } \\
\text { Negatif }\end{array}$ & Perlakuan 1 & & & \\
\hline & Perlakuan 2 & 0,11 & 0,941 & \\
\hline & Perlakuan 3 & 3,31 & 0,042 & Berbeda \\
\hline & $\begin{array}{c}\text { Kontrol } \\
\text { Positif }\end{array}$ & 3,51 & 0,032 & Berbeda \\
\hline \multirow[t]{2}{*}{ Perlakuan 1} & Perlakuan 2 & 0,38 & 0,805 & $\begin{array}{l}\text { Tidak } \\
\text { Berbeda }\end{array}$ \\
\hline & Perlakuan 3 & 3,58 & 0,029 & Berbeda \\
\hline Perlakuan 2 & Perlakuan 3 & 3,20 & 0,049 & Berbeda \\
\hline \multirow{3}{*}{$\begin{array}{c}\text { Kontrol } \\
\text { Positif }\end{array}$} & Perlakuan 1 & 377 & 0,022 & Berbeda \\
\hline & Perlakuan 2 & 3,39 & 0,038 & Berbeda \\
\hline & Perlakuan 3 & 0,19 & 0,900 & $\begin{array}{c}\text { Tidak } \\
\text { Berbeda }\end{array}$ \\
\hline
\end{tabular}

\section{PEMBAHASAN}

Resin akrilik sering digunakan dalam bidang kedokteran gigi sebagai bahan basis gigi tiruan memperbaiki fungsi kunyah, fungsi bicara dan estetis. Suatu gigi tiruan yang ideal seharusnya memiliki warna yang mendekati warna alami. ${ }^{(10)}$ Hal yang perlu diperhatikan pada basis gigi tiruan adalah stabilitas warna, karena sangat penting untuk menyesuaikan dengan jaringan lunak sekitar untuk mempertahankan nilai estetiknya. Semakin sedikit perubahan terjadi maka semakin baik stabilitas warna tersebut. ${ }^{(11)}$

Pada penelitian eksperimental ini digunakan sampel yang berupa plat resin akrilik polimerisasi panas dengan ukuran $10 \times 10 \times 2 \mathrm{~mm}$ serta uji normalitasnya dan homogenitasnya dengan menggunakan uji ShapiroWlik dan Levene's test. Hasilnya menunjukkan data berdistribusi normal ( $>0,05)$ dan data homogen ( $>0,05)$. Pada analisis kemaknaan dengan uji One Way Anova menunjukkan bahwa rerata perubahan warna CIELab $(\Delta \mathrm{E})$ pada kelima kelompok (kontrol negatif, ekstrak 20\%, ekstrak 40\%, ekstrak $60 \%$, dan kontrol positif) berbeda secara bermakna $(\mathrm{p}<0,05)$.

Pengaruh perendaman ekstrak bunga rosella (Hibiscus sabdariffa L.) konsentrasi 20\% dan 40\% terhadap perubahan warna plat resin akrilik polimerisasi panas, dalam penelitian ini ekstrak $20 \%$ dan $40 \%$ di terapkan pada perendaman plat resin akrilik sebagai perlakuan 1 dan 2. Berdasarkan uji LSD diketahui bahwa perlakuan 1 (ekstrak bunga rosella 20\%) dan perlakuan 2 (ekstrak bunga rosella 40\%) ketika dibandingkan dengan kontrol negatif diperoleh hasil bahwa perubahan warna yang terjadi tidak signifikan $(p>0,05)$ atau warna yang dihasilkan oleh perlakuan 1 dan perlakuan 2 sama dengan kontrol negatif. Saat perlakuan 1 dibandingkan dengan kontrol positif diperoleh nilai $\mathrm{p}=0,022$, dan pada perlakuan 2 saat dibandingan dengan kontrol positif diperoleh nilai $\mathrm{p}=$ 0,038 . Sehingga pada perlakuan 1 dan perlakuan 2 ketika dibandingkan dengan kontrol positif menghasilkan perbedaan warna yang signifikan $(\mathrm{p}<0,05)$. Tidak terjadinya perubahan warna disebabkan oleh masih rendahnya kemampuan yang dimiliki ekstrak bunga rosella konsentrasi $20 \%$ dan ekstrak bunga rosella konsentrasi $40 \%$ dalam mempengaruhi perubahan $\mathrm{pH}$ ditandai dengan kepekatan warna yang minim. Hal ini sejalan dengan penelitian yang dilakukan oleh Bahnar (2011), yaitu tidak ada pengaruh perendaman dengan ekstrak bunga rosella konsentrasi $40 \%$ terhadap perubahan warna plat resin akrilik polimerisasi panas.

Pengaruh perendaman ekstrak bunga rosella (Hibiscus sabdariffa L.) konsentrasi 60\% terhadap perubahan warna plat resin akrilik polimerisasi panas, pada penelitian ini ekstrak bunga rosella $60 \%$ dikenal sebagai perlakuan 3. Ketika perlakuan 3 (ekstrak bunga rosella 60\%) dibandingkan dengan kontrol negatif hasilnya adalah terjadi perubahan warna yang signifikan $(\mathrm{p}<0,05)$ dengan nilai $\mathrm{p}=0,042$. Jika dibandingkan dengan kontrol positif maka hasil yang didapat yaitu $\mathrm{p}=$ 0,900 , perbedaan yang terjadi tidak signifikan $(\mathrm{p}>0,05)$. Sehingga dapat diketahui perubahan warna yang terjadi pada perlakuan 3 (ekstrak 60\%) menyerupai perubahan warna yang terjadi pada fifftydent ${ }^{\circledR}$. Ekstrak bunga rosella $60 \%$ memiliki keasamaan yang tinggi yaitu dengan pH 5-6 mengandung asam suksinat, asam oksalat dan asam askorbat, yang lebih tinggi dari jeruk, yang dapat menyebabkan warna merah keunguan yang menjadi bahan pewarna alami pada bunga rosella. ${ }^{(12)}$ sehingga terjadi akumulasi penempelan pigmen warna antosianin pada permukaan plat resin akrilik. Penelitian menemukaan bahwa bunga rosella dapat menghasilkan perubahan warna karena terdapat zat pewarna alami atau stainning agent jenis antosianin menyebabkan warna merah yang berpotensi sebagai pewarna makanan 
dan minuman. Sifat tersebut mengakibatkan zat-zat yang bersifat hidrofolik ekstrak bunga rosella juga mampu terserap oleh resin akrilik polimerasi panas. ${ }^{(8)}$

\section{SIMPULAN}

Berdasarkan hasil penelitian yang telah dilakukan dapat disimpulkan bahwa Konsentrasi perendaman dengan ekstrak bunga rosella (Hibiscus sabdariffa L.) $20 \%$ dan $40 \%$ tidak dapat merubah warna plat resin akrilik polimerisasi panas, sedangkan ekstrak bunga rosella (Hibiscus sabdariffa L.) $60 \%$ dapat merubah warna plat resin akrilik polimerisasi panas.dan konsentrasi perendaman dengan ekstrak bunga rosella (Hibiscus sabdariffa L.) $60 \%$ merupakan konsentrasi optimal yang dapat menyebabkan terjadinya perubahan warna plat resin akrilik polimerisasi panas.

\section{DAFTAR PUSTAKA}

1. Faruqui, S., Haider, S.M., dan Ahmed, N., 2015 , 'Esthetic and function evaluation after treatment with removable dentures by patients, lay persons, dentists in a dental school of pakistan', Pakistan Oral \& Dental Journal, vol. 35, no. 4, hlm. 730-734.

2. Naini, A., 2012, 'Perbedaan stabilitas warna bahan basis gigi tiruan resin akrilik dengan resin nilon termoplastis terhadap penyerapan cairan', Stomatognatic (J.K.G Unej), vol. 9, no. 1, hlm. 2832.

3. Philips, R.W., 2013, Skinner's Science of Dental Materials, Ed. ke-18, W.B Saunders Company, Philadelpia, hlm. 177-215.

4. Putri, S. U. S., 2015, Pengaruh Lama Perendaman Bahan Basis Gigi Tiruan Resin Nilon Termoplastik Dalam Minuman Teh Terhadap Stabilitas Warna,
Skripsi, Fakultas Kedokteran Gigi, Universitas Hasanuddin, Makassar

5. Bahnar, K., 2012, Pengaruh Perendaman Dengan Ekstrak Kelopak Bunga Rosella (Hibiscus Sabdariffa Linn) Sebagai Pembersih Gigi tiruan Terhadap Warna Plat Resin Akrilik, Skripsi, Universitas Hasanuddin, Makasar.

6. Mastuti, E., Gretalia, M. N. W., dan Harlyand, P., 2013, 'Ekstraksi Zat Warna Alami Kelopak Bunga Rosella Dengan Pelarut Etanol', Ekuilibrium, vol. 12. no. 2. hlm. $49-53$.

7. Dharmautama, M., Edy, M., dan Mardi, S, A., 2014, 'Pertumbuhan Bakteri Plak Dan Candida Albicans Pada Basis Gigi tiruan Lepasan Akrilik Setelah Perendaman Dalam Infusa Bunga Rosella', Jurnal Dentofacial, hlm. 2-7.

8. Evan G. Tunggal., Dharmautama, M., dan Jubhari, E,H., 2015, 'Perubahan warna basis akrilik setelah penggunaan pasta pembersih gigi tiruan', Jurnal Dentofasial, vol. 14, no.1, hlm. 25-28.

9. Irfany, Mohamad, D., dan Ike, D., 2014, Stabilitas Warna Basis Akrilik Gigi Tiruan Lepasan Setelah Pembersihan dengan Ekstrak dan Infusa Bunga Rosella, Dentofasial, vol.13, no.1 hlm. 38-42.

10. Noort, R.V., 2013, Introduction to dental materials. Ed. 4, Mosby Elsevier, London, hlm. 261-25.

11. Koksal, T., dan Ahmed, A.S., dan Mutlak, M.F., 2010, 'Modification of some denture cleaning agents employed with mechanical cleansing methods', MDJ, vol. 7, no. 1, hlm. 113-16.

12.12.Rahadian, R., Harun, V., dan Efendi, R., 2017, Pemanfaatan Ekstrak Kelopak Bunga Rosella (Hibiscus sabdariffa L.) dan Rumput Laut (Euchema cottoni) terhadap Mutu Permen Jelly, Fakultas Pertanian, Universitas Riau, Pekanbaru, JOM Faperta UR vol .4, no. 1, hlm 1-6. 